\title{
YIELD AND QUALITY OF SOME TROPICAL SUGARBEET GENOTYPES UNDER BANGLADESH CONDITIONS
}

\author{
M.A.T. Sohel*, M.A.E. Hossain, A.M.S. Rahman, F.H. Shanta and M.R.R. Rajib \\ Bangladesh Sugarcrop Research Institute, Ishurdi, Pabna. \\ *Principle Scientific Officer, Agronomy \& Farming Systems Division \\ Corresponding E-mail: atsohel@yahoo.com
}

(Received: 17 August 2021, Accepted: 19 September 2021)

Keywords: Genotype, yield and quality, tropical sugarbeet

\begin{abstract}
The experiment was conducted at the experimental farm of Agronomy and Farming Systems Division, Bangladesh Sugarcrop Research Institute (BSRI), Ishurdi, Pabna, Bangladesh during 2012-13 cropping season to assess the comparative performance of yield and quality of six tropical sugarbeet genotypes viz., CS 0327, HI 0473, CS 0328, HI 0044, Shubhra and Cauvery. The different genotypes showed significant differences in their yield and yield components, such as beet length, beet girth, beet yield, shoot yield, sugar yield and harvest index. The quality parameters, such as total soluble solids or brix, sucrose percentage and apparent purity percentage of sugarbeet were also different among the genotypes. Maximum beet length $(31.38 \mathrm{~cm})$, beet girth $(36.09 \mathrm{~cm})$, beet yield $(75.46$ $\left.\mathrm{t} \mathrm{ha}^{-1}\right)$, shoot yield $\left(38.46 \mathrm{t} \mathrm{ha}^{-1}\right)$ and sugar yield $\left(11.82 \mathrm{t} \mathrm{ha}^{-1}\right)$ were found in Cauvery followed by CS 0328 . In case of sugarbeet quality, the maximum total soluble solids (TSS) and sucrose percentage $(21.90 \%$ and $15.68 \%$, respectively) were recorded in Cauvery followed by the genotype CS 0328 (21.52\% and $15.50 \%$, respectively). So, it was concluded that tropical sugarbeet genotype Cauvery appeared as the best one with respect to yield and quality parameters followed by CS 0328 under Bangladesh conditions.
\end{abstract}

\section{Introduction}

Sugarbeet (Beta vulgaris) is one of the most important sugar crops of temperate climates (AbdelMotagally and Attia, 2009). It ranks the second as sugar crop after sugarcane in the world. Sugarbeet is a fleshy root crop processed for sugar production. Sugarbeet is mainly a temperate crop but can be successfully grown under tropical climatic conditions. Sugarbeet growth, yield and quality are influenced by different variety, spacing, various agronomic practices, fertilizer management, date of sowing etc. Choosing the sugarbeet hybrid with high yield potential is important as well as good adapted agronomic measures and practices, synchronized with requirements and needs of the plant (Ulakovic et al., 2015).

Variety plays an important role on the performance of tropical sugarbeet. All sugarbeet genotypes cultivated in Bangladesh are imported from foreign countries; so, it is preferable to evaluate them under Bangladesh conditions especially under newly reclaimed soil to select the best suited ones. Yield and yield parameters of sugarbeet differed significantly among the varieties /lines (Bairagi et al., 2013). Lamani and Halikatti (2019) observed that the genotype Cauvery recorded significantly higher yield, yield attributes and quality parameters than genotype Indus. BRAC (2010) conducted field experiment with nine varieties/lines in Patuakhali and Noakhali, i.e. in the coastal area of Bangladesh. Among the nine sugarbeet varieties/lines Cauvery gave the highest beet yield $\left(120 \mathrm{tha}^{-1}\right)$ and proved to be highly tolerant to salinity. Hossain et al. (2011) conducted an experiment in Bangladesh Agricultural University farm, Mymensingh with five sugarbeet varieties/lines, where EB-0809 gave the highest 
yield $\left(89.74 \mathrm{t} \mathrm{ha}^{-1}\right)$ compared to other varieties. Sugarbeet is a new crop in Bangladesh and until now it has not been grown commercially in a large scale. Systematic research to improve the yield and quality of sugarbeet through best agronomic practices is also scare. Considering the above facts, the present study was carried out to evaluate yield, yield related parameters and quality of six selected tropical sugarbeet genotypes under Bangladesh conditions.

\section{Materials and Methods}

The experiment was conducted at BSRI farm, Ishurdi (AEZ-11) during rabi cropping season of 201213 following a Randomized Complete Block Design with three replications. Each plot size was $4.0 \mathrm{~m} \times$ $4.0 \mathrm{~m}$ i.e. $16 \mathrm{~m}^{2}$. The seeds were sown on 04 November 2012 at about $2 \mathrm{~cm}$ depth at a distance of 50 $\mathrm{cm}$ from line to line and $20 \mathrm{~cm}$ from plant to plant. Six tropical sugarbeet genotypes, viz. CS $0327, \mathrm{HI}$ 0473, CS 0328, HI 0044, Shubhra and Cauvery were used as treatment materials. The land was uniformly fertilized with $260 \mathrm{~kg}$ urea, $100 \mathrm{~kg}$ triple super phosphate (TSP), $225 \mathrm{~kg}$ muriate of potash (MoP), $100 \mathrm{~kg}$ gypsum, $10 \mathrm{~kg}$ zinc sulphate and $7 \mathrm{~kg}$ boric acid $\mathrm{ha}^{-1}$ (BSRI, 2011). Three weedings were done at 30,50 and 70 DAS for the study. Plants were thinned at the age of 35 days after sowing to obtain one plant per hill. Earthing-up was done to cover the root base and to facilitate drainage operation. The experimental field required 3 irrigations applied at 45, 90 and 125 DAS.

Data on yield and yield contributing components, viz. beet length, beet girth, beet yield, shoot yield, sugar yield, harvest index, total soluble solids or brix, sucrose percentage and apparent purity percentage were collected following standard methods. All data were statistically analyzed according to the technique of analysis of variance (ANOVA) by means of "STATISTIX-10" Computer software package for windows version (Statistix-10, 2013) and least significant difference (LSD) method was used to test the differences between treatment means at $5 \%$ level of probability.

\section{Results and Discussion}

Yield, yield contributing characters and quality in respect of beet length $(\mathrm{cm})$, beet girth $(\mathrm{cm})$, beet yield $\left(\mathrm{t} \mathrm{ha}^{-1}\right)$, shoot yield $\left(\mathrm{t} \mathrm{ha}^{-1}\right)$, sugar yield $\left(\mathrm{t} \mathrm{ha}^{-1}\right)$, harvest index $(\mathrm{HI})$, total soluble solids (TSS \%) or brix $(\%)$, sucrose percentage (\%) and apparent purity percentage (\%) are presented and discussed here under:

\section{Yield and Yield Components}

\section{Beet length and beet girth}

Beet length and beet girth were significantly responded to different sugarbeet genotypes at harvest (Fig. 1 and Fig. 2). The maximum beet length and beet girth $(31.38 \mathrm{~cm}$ and $36.09 \mathrm{~cm})$ was obtained from the variety Cauvery which was statistically similar with CS $0328(29.99 \mathrm{~cm}$ and $35.01 \mathrm{~cm})$, respectively. The lowest beet length $(27.80 \mathrm{~cm})$ and beet girth $(30.33 \mathrm{~cm})$ was measured from HI 0044 and Shubhra, respectively. Enan et al. (2009), Hossain et al. (2011) and Bairagi et al. (2013) were also found genotypic differences in beet length and girth. 


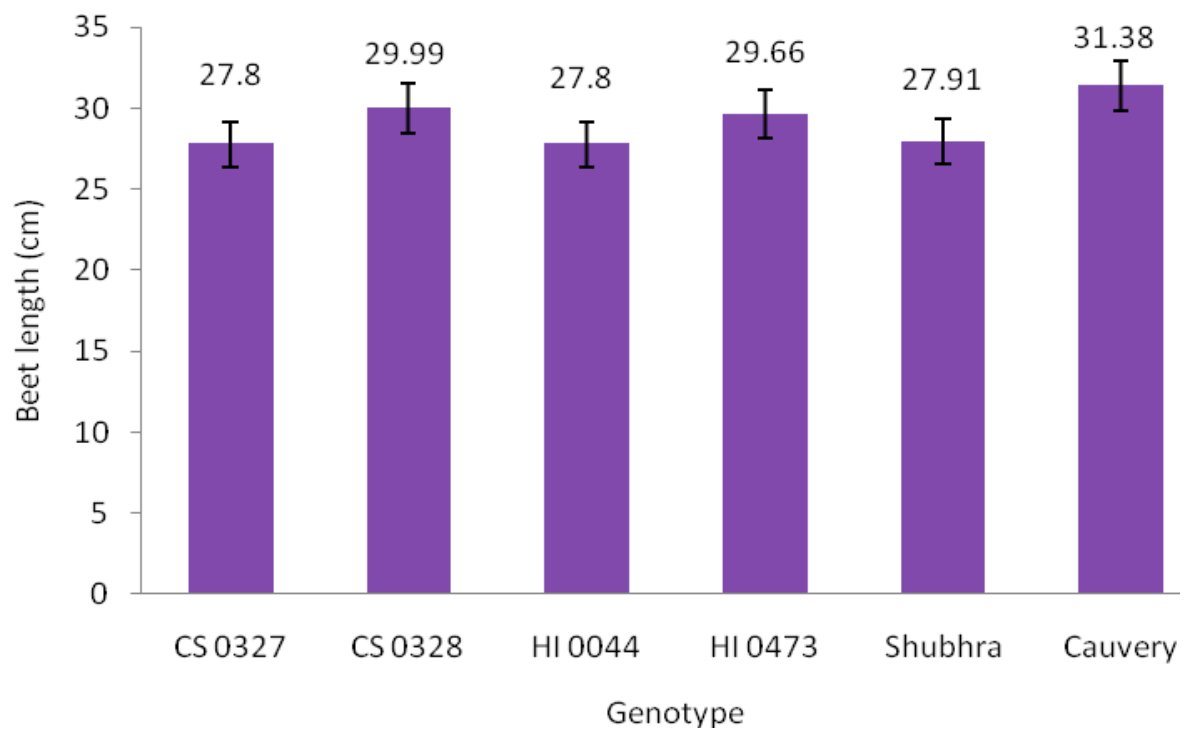

Fig. 1. Effect of genotypes on beet length of six tropical sugarbeet genotypes at harvest.

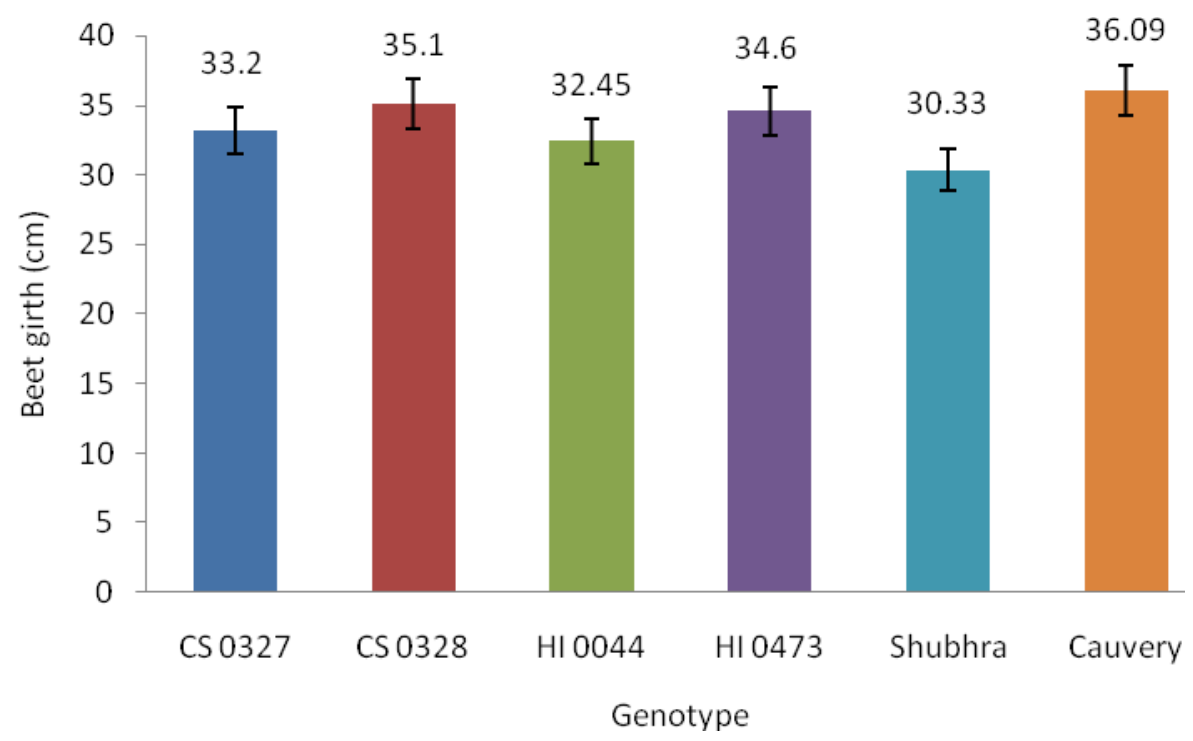

Fig. 2. Effect of genotypes on beet girth of six tropical sugarbeet genotypes at harvest.

\section{Beet yield and shoot yield}

Beet and shoot yield were significantly influenced by sugarbeet genotypes at harvest (Fig. 3 and 4). Among the genotypes, the maximum beet yield and shoot yield $\left(75.46 \mathrm{t} \mathrm{ha}^{-1}\right.$ and $38.46 \mathrm{t} \mathrm{ha}^{-1}$, respectively) was recorded in Cauvery, which was statistically similar with CS 0328 (72.07 $\mathrm{t} \mathrm{ha}^{-1}$ and $37.59 \mathrm{t} \mathrm{ha}^{-1}$, respectively), while the lowest yield (57.57 $\mathrm{t} \mathrm{ha}^{-1}$ and $25.25 \mathrm{t} \mathrm{ha}^{-1}$, respectively) obtained from Shubhra. The highest beet yield and shoot yield were attributed to the higher number of leaves plant $^{-1}$, individual beet and shoot fresh weight plant ${ }^{-1}$. These results agreed with the findings of BRAC (2010), Jozefyova (2004), Rahman (2011) and Badawi et al. (2003) that genotypic differences influenced the plant morphological characters. 


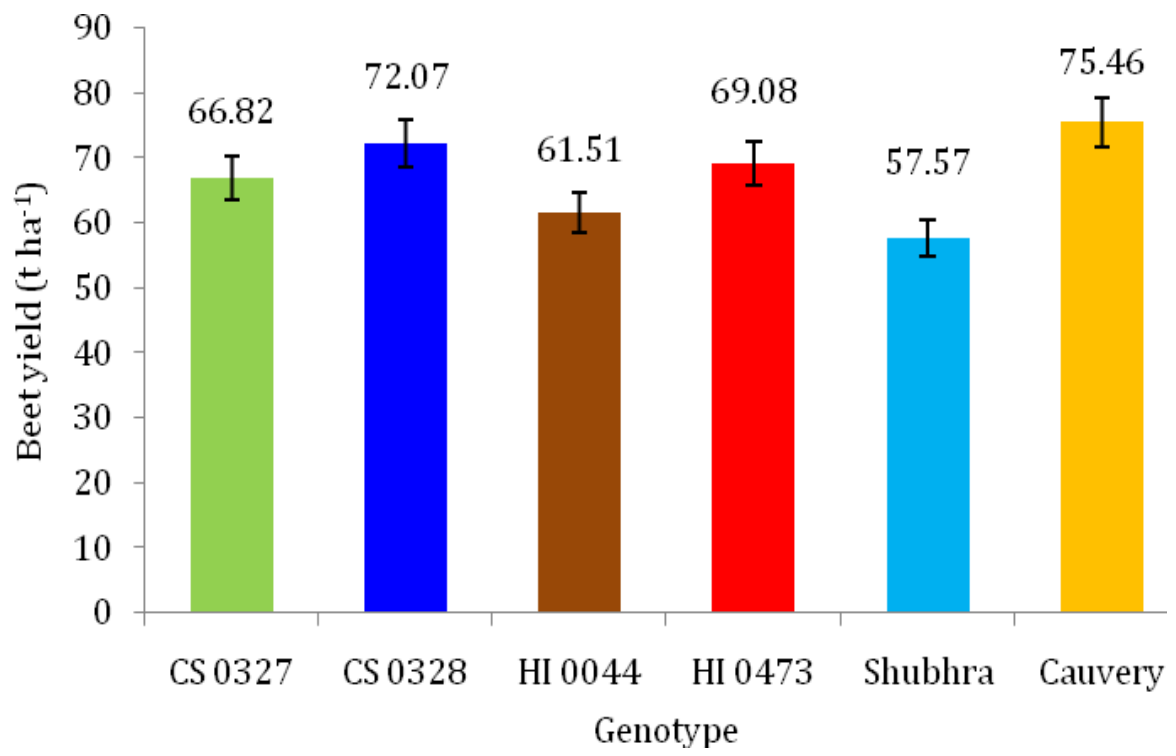

Fig. 3. Effect of genotypes on beet yield of six tropical sugarbeet genotypes at harvest.

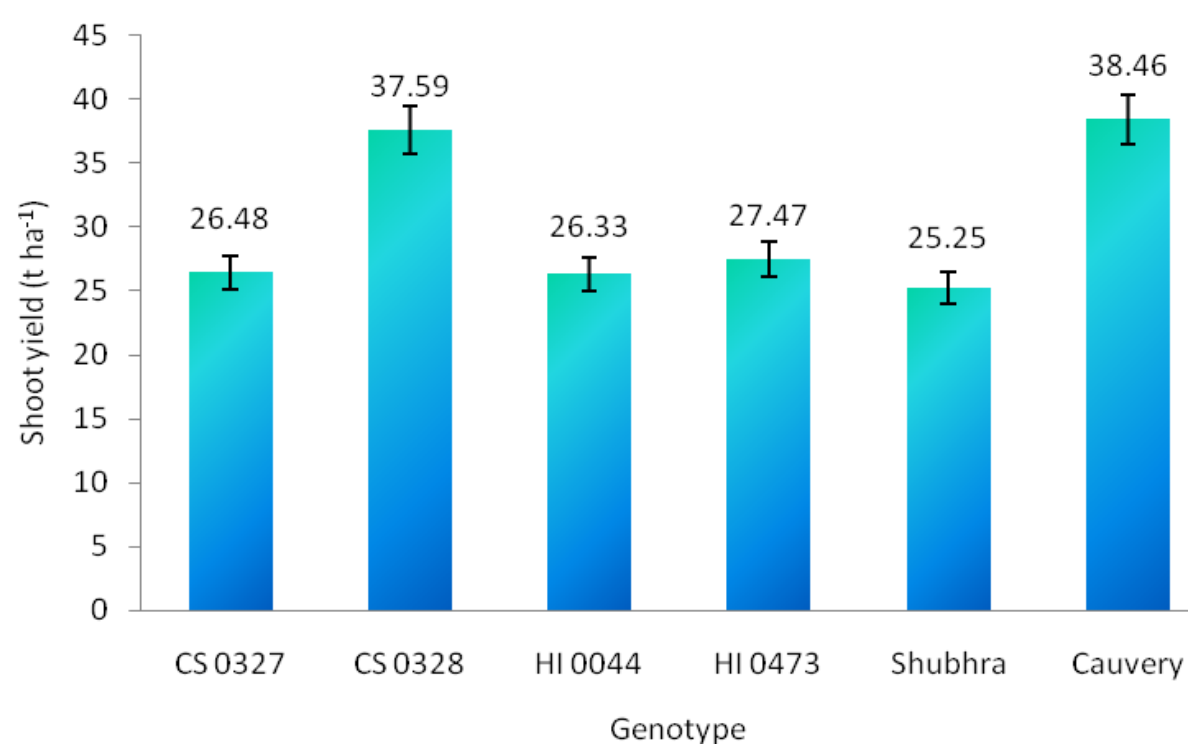

Fig. 4. Effect of genotypes on shoot yield of six tropical sugarbeet genotypes at harvest.

\section{Sugar yield and harvest index (HI)}

Sugar yield and harvest index were significantly influenced by tropical sugarbeet genotypes at harvest (Fig. 5 and 6). The maximum sugar yield $\left(11.82 \mathrm{t} \mathrm{ha}^{-1}\right.$ ) was found in Cauvery followed by CS 0328 $\left(11.17 \mathrm{t} \mathrm{ha}^{-1}\right)$ and genotype HI 0044 gave the lowest amount of sugar yield $\left(8.58 \mathrm{t} \mathrm{ha}^{-1}\right)$. The highest value of harvest index was achieved in genotype CS 0327 (0.716), and the genotype CS 0328 gave the lowest (0.657). Sugar yield varied significantly due to significant difference in beet yield. The results reflected that genotype Cauvery and CS 0328 was the suitable genotype in terms of sugar yield. Similar findings were reported by Marlander and Rothe (2005), Azzazy et al. (2007) and Aly (2006) that there was a significant genotypic difference in producing sugar yield under tropical conditions. 


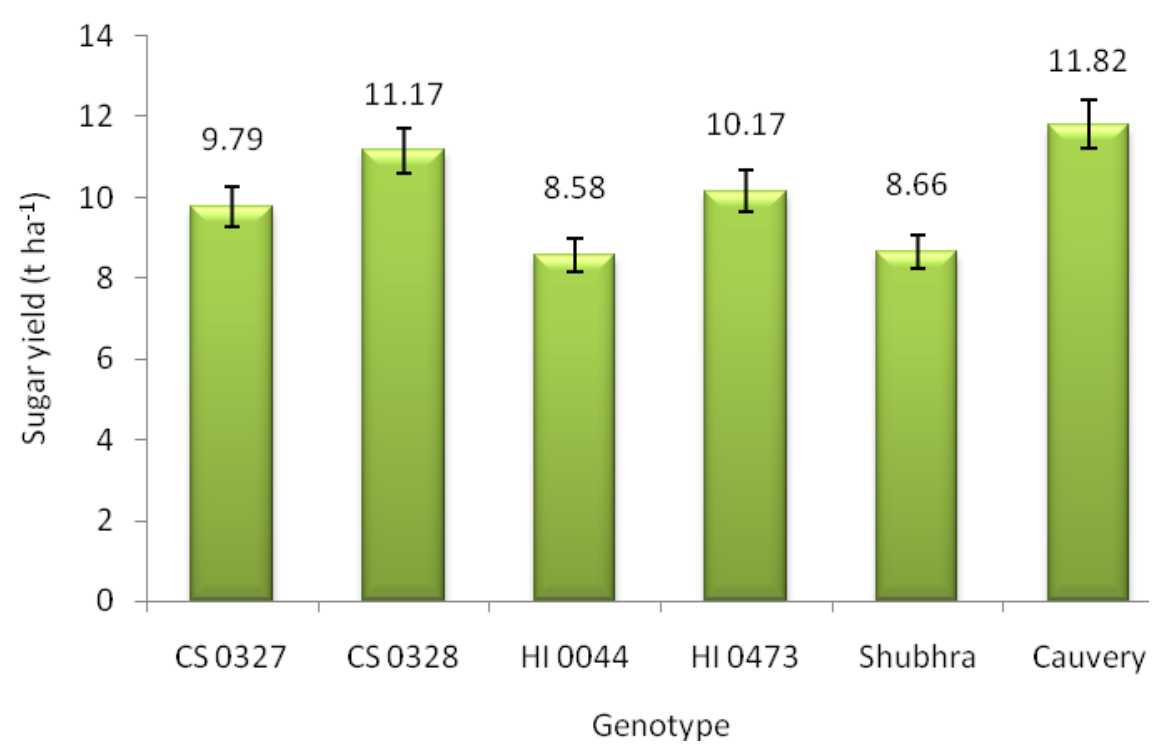

Fig. 5. Effect of genotypes on sugar yield of six tropical sugarbeet genotypes at harvest.

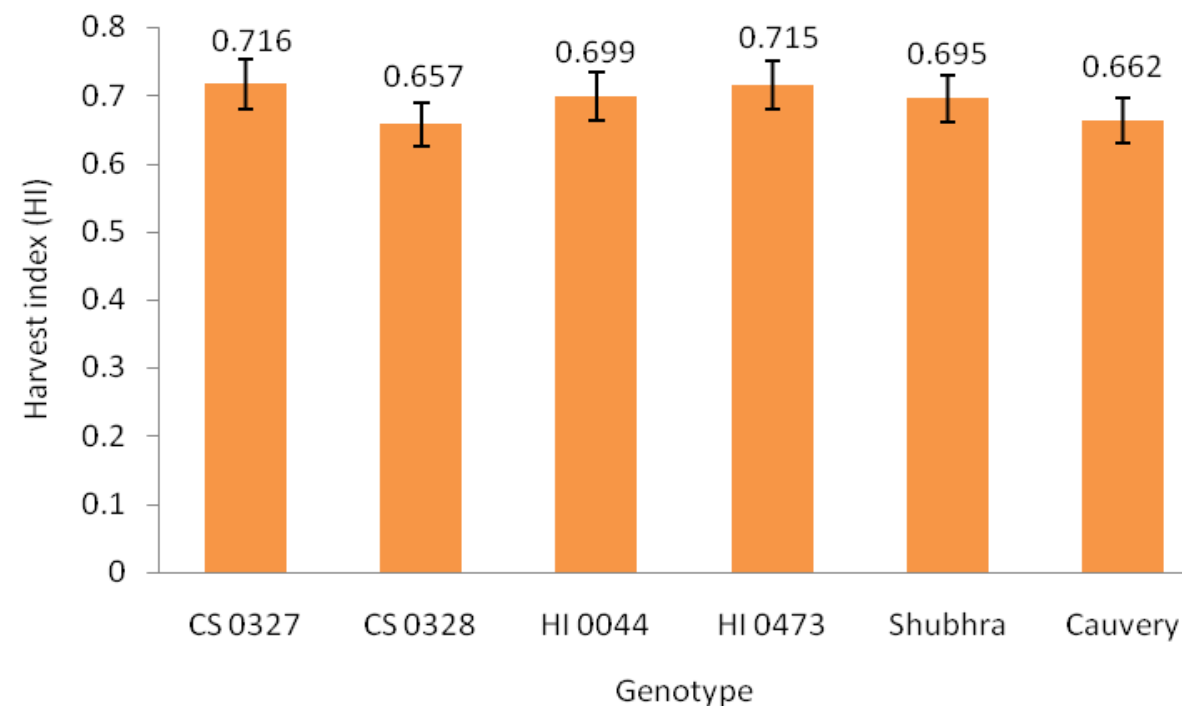

Fig. 6. Effect of genotypes on harvest index of six tropical sugarbeet genotypes at harvest.

\section{Beet Quality Characters}

\section{Total soluble solids or Brix}

Genotypes were significantly influenced the total soluble solids in juice of tropical sugarbeet root (Table 1). The maximum TSS $(21.90 \%)$ was recorded in Cauvery followed by CS $0328(21.52 \%)$ where the genotype HI 0044 gave the lowest TSS (19.79\%).

\section{Sucrose percentage}

Sucrose percentage in tropical sugarbeet was significantly influenced by the genotypes (Table 1). The results revealed that Cauvery had the maximum concentration of sucrose $(15.68 \%)$, which was 
statistically similar with CS 0328 (15.50\%). The lowest concentration (13.95\%) of sucrose was found in the genotype HI 0044. Superiority at TSS and sucrose \% may be due to the genetic structure of this variety. This result was in agreement with the findings of Ntwanai and Tuwanai (2013), Osman et al. (2003), Islam et al. (2012) and Enan et al. (2009) also that sucrose content varied due to genotypic differences.

Table 1. Total soluble solids, sucrose percentage and apparent purity percentage of sugarbeet as affected by genotypes at harvest

\begin{tabular}{cccc}
\hline $\begin{array}{c}\text { Treatments } \\
\text { (Variety) }\end{array}$ & \multicolumn{3}{c}{ Beet quality characters } \\
\cline { 2 - 4 } & $\begin{array}{c}\text { Total soluble solids } \\
\text { (TSS \%) or Brix (\%) }\end{array}$ & $\begin{array}{c}\text { Sucrose percentage } \\
(\%)\end{array}$ & $\begin{array}{c}\text { Apparent purity } \\
\text { percentage (\%) }\end{array}$ \\
\hline CS 0327 & $20.41 \mathrm{c}$ & $14.65 \mathrm{c}$ & $71.79 \mathrm{a}$ \\
CS 0328 & $21.52 \mathrm{a}$ & $15.50 \mathrm{a}$ & $72.04 \mathrm{a}$ \\
HI 0044 & $19.79 \mathrm{~d}$ & $13.95 \mathrm{~d}$ & $70.50 \mathrm{~b}$ \\
HI 0473 & $20.65 \mathrm{bc}$ & $14.73 \mathrm{c}$ & $71.32 \mathrm{ab}$ \\
Shubhra & $21.04 \mathrm{~b}$ & $15.03 \mathrm{~b}$ & $71.41 \mathrm{ab}$ \\
Cauvery & $21.90 \mathrm{a}$ & $15.68 \mathrm{a}$ & $71.60 \mathrm{ab}$ \\
\hline CV $(\%)$ & 1.28 & 1.05 & 1.15 \\
LSD $_{(0.05)}$ & 0.40 & 0.24 & 1.23 \\
\hline
\end{tabular}

In a column, figures with a similar letter do not differ significantly and those with dissimilar letter significant at $5 \%$ level.

\section{Apparent purity percentage}

Apparent purity percentage of tropical sugarbeet was significantly influenced by the different genotypes. The maximum apparent purity percentage $(72.04 \%)$ was obtained from CS 0328 followed by CS $0327(71.79 \%)$ and the lowest $(70.50 \%)$ purity percentage was appeared in genotype HI 0044 .

\section{Conclusion}

It may be concluded that among the six genotypes, Cauvery showed the better performance in all aspect of yield and quality parameters of sugarbeet, except harvest index and apparent purity percentage followed by the genotype CS 0328 in all the studied charactyers. Hence, the sugarbeet genotypes Cauvery and CS 0328 could be selected for further evaluation under different field conditions before going for cultivation commercially in Bangladesh.

\section{References}

Abdel-Motagally, F.M.F. and K.K. Attia. 2009. Response of sugarbeet plants to nitrogen and potassium fertilization in sandy calcareous soil. Int. J. Agric. Bio. 11: 695-700.

Aly, E.F. 2006. Effect of environmental conditions on productivity and quality of some sugarbeet varieties. Ph. D. Thesis. Fac. of Agric. Benha Univ., Egypt.

Azzazy, N.B., N.M.S. Shalaby and A.M. Abd El-Razek. 2007. Effect of planting density and days to harvest on yield and quality of some sugarbeet varieties under Fayoum condition. Egypt. J. Appl. Sci. 22(12A): 101-14.

Badawi, M.A., M.A. EL-Agroudy and A.N. Attia. 2003. Effect of sowing dates and NPK fertilization on growth and yield of sugarbeet (Beta vulgaris L.). J. Agric. Sci. 20(6): 2683-2689.

Bairagi, A., S.K. Paul, M.A. Kader and M.S. Hossain. 2013. Yield of tropical sugarbeet as influenced by variety and rate of fertilizer application. Pak. Sugar J. 28(4): 15. 
BRAC. 2010. Project report on sugarbeet cultivation, Bangladesh Rural Advancement Committee, pp.13-16.

BSRI. 2011. Sugarbeet cultivation in Bangladesh. Bangladesh Sugarcrop Research Institute. Ishurdi, Pabna, Bangladesh. p.4.

David, D. and A. Young. 1981. Soil survey and land evaluation. George Allen and Unwin publishers Ltd, 40 Museum Street, London WC1A 1LU UK.

Enan, S.A.A.M., S.R.E. El-Sheikh and K.A.M. Khaled. 2009. Evaluation of some sugarbeet varieties under different levels of N and Mo fertilization. J. Agric. Bio. Chem. Envir. Sci. 4(1): 345-362.

Hossain, M.M., M.A. Kader and M.A. Kashem. 2011. Effects of sowing date and variety on the yield of tropical sugarbeet (Beta vulgaris L.). B. Agro. J. 14(1\&2): 95-101.

Islam, M.S., S. Ahmad, M.G. Uddin and M.A. Sattar. 2012. Evaluation of tropical sugarbeet genotypes under Bangladesh condition. J. Agric. Res. 37(4): 721-728.

Jozefyova, L. 2004. Effect of harvest time on sugarbeet fertilized with increased nitrogen. WFL Publisher Science and Technology. Food, Agric. Envir. 2(1): 232-237.

Lamani, K.D. and S.I. Halikatti. 2019. Performance of sugarbeet genotypes and date of sowing on yield and quality parameters. Advan. Res. 18(2): 1-7. doi: 10.9734/AIR/2019/46696.

Marlander, B. and I. Rothe. 2005. Zuckerrubenanbau im wandel der Zeit-Herausforderung, Inovation und Entwicklungspotencial. Zuckerindustrie 130(6): 482-486.

Ntwanai, B. and S.W. Tuwanai. 2013. Effect of planting date on yield and sugar content of sugarbeet cultivars grown in Cradock, Eastern Cape. African Crop Science Conference Proceedings 11: 5154.

Osman, A.M.H., G.S. El-Sayed, M.S.H. Osman and K.S. El-Sogheir. 2003. Soil application of some microelements with relation to yield and quality of sugarbeet varieties. Ann. Agric. Sci., Moshtohor, 41(3): 1071-1088.

Rahman, M.K. 2011. Feasibility of sugarbeet cultivation in Bangladesh: A Review (Handbook in Bangali version). Bangladesh Sugarcrop Research Institute. Ishurdi, Pabna, Bangladesh. pp.1-10.

Shahl, I.H., N.U. Khanl, G. Flasool and N. Saeed. 2000. Effect of sowing time and plant population on root yield and accumulation of sugar in sugarbeet. Pak. J. Bio. Sci. 3(12): 2005-2007.

Statistix 10. 2013. Analytical Software. Tallahassee, Florida, USA.

Syngenta. 2004. Syngenta Bangladesh Ltd. http// Sugarbeet.ucdavis.edu/ SBPM/Nutrients/ fig1. GIF. www. Sugarproducer.com, 2011. Sugar Producer Magazine.

Ulakovic, V., N. Glamoclija, V. Filipovic and V. Ugrenovic. 2015. Mineral nutrition plants in function of stable sugarbeet production. Selekcija i Semenarstvo 21: 39-49. doi: 10.5937/SelSem1502039D. 